\title{
The Hindu Aristotle
}

\author{
Bradley Y. Bartholomew \\ Independent Researcher
}

\begin{abstract}
This paper presents an original interpretation of the Upanishads that the inner self is located in the embryo brain region of the brain. This is the part of the brain already present in the embryo and consists of the brainstem, hypothalamus, thalamus, and midbrain. It is also the part of the brain that operates during dreaming and deep sleep and causes the transition from sleeping to waking states, and the Upanishads state unequivocally that the self is responsible for these mental states. With the self located in the embryo brain region, an entirely new interpretation of Aristotle's De Anima is presented which parallels the Upanishads in every respect; the inner self and Aristotle's "soul" have identical functions and attributes. An Aristotelian First Principle is presented: Biology is the source of Consciousness; DNA is the source of Biology; Ergo DNA is the source of Consciousness.
\end{abstract}

Keywords: psyche, nous, Metaphysics, Pythagoras, REM sleep, substance, form, matter, Plato, respiration

\section{Introduction}

It is generally believed that Hindu philosophy as expounded in the Upanişads is a totally different system of thought from the philosophy of Aristotle as expounded in his famous works Metaphysics and De Anima. This conviction that Hindu philosophy and Aristotelian philosophy are different schools of thought has indeed become entrenched in the history of humanity where the religion and culture of India is considered to be based on mysticism as a result of the inscrutable nature of their divine texts, whereas the teachings of Aristotle, which indeed are just as inscrutable, are considered to provide a firm foundation for the edifice of knowledge that has accrued in the West under the banner of scientific exploration and experimentation; such a noble enterprise being indeed the absolute antithesis of mysticism.

This is notwithstanding the fact that Hindu philosophy and Aristotelian philosophy share a fundamental common theme which is completely clear and unambiguous and universally accepted; both these schools of thought are talking about a divine and immortal mind or soul. Indeed book Epsilon of Metaphysics begins by identifying the study of being with the study of God. Evidently if an interpretation can be found of the Upanişads which locates the inner self precisely in the brain and specifies its precise form and functions then the most efficacious way to test the veracity of that theory would be to see if it is also a good fit with what Aristotle says about the immortal soul or mind in his De Anima. It just so happens that there is such a theory which was published in the Indian Philosophical Quarterly 25 years ago and it is the purpose of this paper to present that theory in the Western academic literature and then to see how it stacks up with what Aristotle had to say. 


\section{Parallels between Ancient Greek and Hindu Philosophy}

I will just take a moment to recall just how the philosophies of India and of the Ancient Greeks both emerged completely independently of each other around the same period approximately 2,500 years ago and the fundamental precepts in these different philosophies enshrined in the dead languages of Sanskrit and Ancient Greek are virtually identical. Both the Hindus and the Ancient Greeks believed in a divine and immortal mind or soul that entered the body at conception, they believed in the transmigration of souls and they believed that the external world that we perceive through the senses is ultimately unreal. There were many ancient Greek philosophers and they all famously had different theories and they did not all agree with all three of these fundamental precepts above, but I think I can state without fear of contradiction that these three precepts were the dominant themes in early Greek philosophy and they enjoyed a broad consensus. Aristotle himself took issue with his master Plato on this topic of the unreality of the sensible world, but he was very clear on the fact that there is a divine and immortal soul which is actually tangible; it has form and matter or substance. We shall see in this regard that Aristotle's thinking substantially parallels that of the Hindus, and this is now about 2,300 years ago, and there still had not been any contact or exchange at all between the cultures of India and ancient Athens.

\section{The Location of the Inner Self}

An article was published in the Indian Philosophical Quarterly in India in 1991 entitled "Inner Self Located" which locates the inner self in the embryo brain region (Bartholomew 1991). This is the part of the brain that is already present in the embryo and it consists of the brainstem, hypothalamus, thalamus, and midbrain. In other words, the inner self is a real substantial part of the brain that has certain form and matter. I mention this at the outset because this will become crucial when I get onto the works of Aristotle. This is also the part of the brain that operates during sleep, that is to say it is responsible for the states of being awake and asleep; it is the source of our dreams and it is the part of the brain that causes the transition from the sleeping state to the waking state. The article to which I refer sets out a great deal of mainstream scientific evidence for all the above propositions and I don't propose to repeat that here. When I get onto the specific functions of the hypothalamus, thalamus, brainstem, and midbrain, you will see that it is beyond question that the embryo brain region is the part of the brain that operates during sleep.

It can be no exaggeration to say that the state of sleep is the very cornerstone of Hinduism. According to the Kața Upanişad, Puruşa, "who keeps awake and goes on creating desirable things, even when the senses fall asleep, is pure; and He is Brahman and He is called the Immortal. All the worlds are fixed on Him; none can transcend Him" (Eight Upanişads, 1981). This Puruşa is called thus because He sleeps in all bodies (Puriśaya) (Bŗhadāranyaka Upanişad, 1978). On an individual plane, this Puruşa or Brahman is known as $\bar{A} t m a n$ or the Self.

Two states of sleep are distinguished. There is first the dream consciousness which is evoked and sustained by the Self. "The blissful Self, revived by the impression of joy etc., is perceived in dream..." (Śańkarācārya's Commentary on the Taittirīya Upanişad) (Eight Upanişads, 1981). "That radiant infinite Being... puts the body aside in the dream state" (Bŗhadäranyaka Upanişad, 1981). "Puruşa is the Supreme Person, who Himself becomes manifest as the persons in the eye and in dream..." (Śańkarācārya's Commentary on the Chāndogya Upanişad) (Chāndogya Upanişad, 1983). 
There is secondly the state of deep sleep. “... then the sleeper becomes merged in Existence. He attains his own Self. Therefore, they speak of him as, 'he sleeps' for he attains his own Self' (Chāndogya Upanişad, 1983). “... they reach daily (during sleep) this Brahman which is the goal” (Chāndogya Upanişad, 1983). "In deep sleep Puruşa remains unmanifest and His organs fully withdrawn" (Śańkarācārya) (Chāndogya Upanişad, 1983).

The Self is consistently stated to be the agent that brings about the transition from the sleeping state to the waking state. "... it hastens back in a reverse way just to its previous state, that of waking..." (Bŗhadāranyaka Upanişad, 1951). "As a large fish swims alternately to both banks (of a river) eastern and western even so does this infinite entity move alternately to both these states - those of dreaming and waking" (Bŗhadäranyaka Upanişad, 1951). "While the Self withdraws itself from all manifestations when it is in deep sleep, it projects itself in waking through the very channels through which it withdrew itself in sleep" (Bŗhadāranyaka Upanişad, 1984).

Aristotle, the former pupil of Plato at the Academy, himself became the head of Lyceum, also in Athens and considered to be the world's first university. His major point of departure from Plato was this notion that that which changes is ultimately unreal, and now the prime task of the science of nature would be to find an explanation for this change. The Platonic soul had to have form and matter, otherwise his students wouldn't have anything to actually study at his Lyceum. Unfortunately, this raised more questions than it answered, and 2,300 years later scientists and philosophers and academics are still trying to figure out what he meant. Generally speaking, he was stating that there is a close correspondence between the arrangement and the functioning of any living being, but that is a long way from explaining how the soul, which definitely contained a divine component, could also have form and matter, or another term he used for this soul was "substance;" the divine soul had to have substance.

This of course is only perplexing for occidental philosophers, because it has been known all along in India that the divine inner self does indeed have substance, or form and matter. Śańkarācārya explains the meaning of the word angușthamatrah - "of the size of a thumb, the lotus of the heart is of the size of a thumb; (and) as conditioned by the internal organ existing in the space within the lotus of the heart (the Self) has the size of a thumb" (Eight Upanişads, 1981). The Chāndogya Upanişad states: "This Self of mine within the heart, is smaller than paddy or barley or mustard or a Shyamaka seed, or the kernel of Shyamaka seed. This Self of mine within the heart is greater than the earth, greater than the interminable space, greater than the heaven, greater than the worlds" (Chāndogya Upanişad, 1983).

"The desire is for knowing some special director of the mind" (Ananda Giri). "Who is that effulgent being who is the director of the mind and other organs towards their own objects and how does he direct?" (Śańkarācārya's Commentary on the Iśa Upanişad) (Eight Upanişads, 1981) "He is all-pervasive, pure, bodiless, without wound, without sinews, taintless, untouched by sin, omniscient, ruler of the mind, transcendent and self-existent" (Iśa Upanişad) (Eight Upanişads, 1981). This "special director," this "ruler" of the mind has to be the part of the brain that determines the growth and development of the whole brain, i.e., the embryo brain region.

"As the spider weaves out the web and again withdraws it, so the Jiv $a$ comes out to and goes back again to the wakeful and dreaming states respectively" (Brahmopaniśad) (Bŗhadāranyaka Upanişad, 1984). This reference to the Self being like a spider that casts out and withdraws its web occurs a number of times in the Upanişads. It is consistent with the Self being located in the hŗdaya (heart) that goes by drawing and giving. It 
would appear to be an illustration of the way the Self, lodged in the embryo brain region by means of the neurotransmitter, noradrenaline, draws the individual into sleep, and by means of the neurotransmitter, dopamine, wakes the individual up again. These neurotransmitters emanate from the embryo brain region in spider web pattern through the network of nerve channels in the brain. "And when a man is about to wake up, they emanate - they proceed to their respective functions - from the mind itself just like the rays radiating from the sun" (Śańkarācārya's Commentary on the Praśna Upanişad) (Eight Upanişads, 1957).

That the embryo brain region is the location of the Self is consistent with the many references in the Upanişads to the Self being the "seed," "the source," "the creator." "In a person, indeed this one first becomes an embryo" (Aitareya Upanişad) (Principal Upanişads, 1989). "It is the seed of all activity, that is to say, it is the state of deep sleep. That (mental state) is called jñānam, knowledge..." (Śańkarācārya) (Eight Upanişads, 1957). By the fifth week after fertilization, the embryo cranium is bulging with midbrain that is firing spontaneously. This is the vital force. "It is like that which is known as the flash of lightning, and It is also as though the eye winked" (Kena Upanişad) (Eight Upanişads, 1981). "The vital force enters into the womb along with the seed and it develops itself into the embryo and all the other limbs such as the eye, the ears and the rest manifest themselves subsequently" (Sivananda) (Bŗhadāraņyaka Upanişad, 1985).

The embryo brain consists of the thalamus, hypothalamus, midbrain, and brainstem. These are the specific areas of the brain that are discernible about five weeks after conception. As the brain grows and expands, these areas remain the central core and guiding influence. It is mentioned in passing that the thalamus and hypothalamus comprise a part of the brain known as the diencephalons which also contains the pineal body. A special significance for this pineal body is not ruled out, although there is little neurophysiological evidence as to its functions.

The hypothalamus is responsible for the states of being awake or asleep which are pivotal in our lives. It is said to organize, when electrically stimulated, total acts of aggression, timidity, mating, and sexual behavior in animals. As to these last mentioned aspects, compare the content both of our dreams and our thoughts, where themes such as these regularly occur. In terms of human emotion, we would talk of hatred, fear, love, and desire. The hypothalamus apparently directs our mental processes from the very beginning, and is responsible for all our emotions. The hypothalamus is also considered responsible for the autonomic nervous system which directs all the myriad functions that take place in our body over which we have no conscious control-functions relating to circulation, respiration, digestion, excretion, regulation of body temperature and metabolism, regulation of water content, and reproduction. The fact that the hypothalamus remains a relatively small area in the developed adult brain merely attests to its potency, and to the fact that it was performing functions just as complex in the embryo period when it was very small indeed. Hence references in the Upanişads to the Self being of the size of a thumb or less. The entire embryo brain region in the adult brain is indeed about the "size of a thumb." The hypothalamus itself has a rostrocaudal extent of about $10 \mathrm{~mm}$ (Carpenter 1978).

Compare the fact that the hypothalamus controls respiration with the passage in the Bŗhadäranyaka Upanişad, "That which breathes by the breath is thy soul which is within every being" (Bŗhadäranyaka Upanişad, 1978). It is also known that the fetus in the womb practices breathing movements specifically during REM sleep (Austin \& Short 1972). Another factor indicating the workings of the Self in the embryo brain region; the source of respiration and dreams: "Now he who, without stopping the respiration, goes upwards, moving about yet unmoving, dispels darkness, he is the Self" (Maitreyi Upanişad) (Chāndogya Upanişad, 1983). 
The thalamus has extensive connections with the higher regions of the brain and determines what will become conscious to us. Fibers from the thalamus are connected as well to neurons of the central nervous system, gustatory, auditory, visual, and from the skin, the organs of balance, the bladder, the alimentary canal, the muscles and joints. The Upanişads speak about precisely these nerves emanating from the heart. "Again when (this person) is fast asleep, when (he) knows nothing whatsoever returning in the body with the 72 thousand nerves by name hita which proceed from the heart to all parts of the body, he sleeps" (Bŗhadāranyaka Upanişad, 1985).

By five months of gestation, increased brain wave activity is noted with the onset of activity around the thalamus (Pecile \& Muller 1971). This is consistent with the thalamus acting as a mediator or "go-between" between the embryo brain and the higher regions of the fetus's brain that are by now substantially developed. And it is likewise consistent with the brain wave activity in the adult where there are 10/sec rhythmical brainwaves that are considered to comprise a loop between the cortical regions and the thalamus (Remond 1972). There are a number of theories about the precise pathway that the loop takes but the concept of the thalamus as a "go-between" is reinforced by Baron Edgar Adrian's observation that rhythmic thalamic activity persists even if substantial areas of the cortex are removed-indeed even if the whole cortex is removed! Further reinforcement comes from the theory that the thalamus acts as a central "pacemaker" for cortical rhythmical activity, which implies that command signals from a small thalamic region are distributed to wide areas of the cortical mantle (Remond 1972).

The importance of the brainstem is certainly on a par with the other areas of the embryo brain because a system of projections are in place here by the end of the embryo period ( 8 weeks) which influence the growth and development of the cortical (higher) regions. It is generally concerned with the states of arousal—sleeping, waking, relaxation, alertness, vigilance etc. Sensory input from the receptors does not reach the anatomical substrate of consciousness while we are asleep because of the operation of the brainstem; if the input is urgent it awakens us (Gregory 1987). "The nerve that rises upward from the heart is their passage for moving (from the dream state to the waking state); it is like a hair split into a thousand parts. (Numerous) nerves of this body, called Hita are rooted in the heart" (Bŗhadāranyaka Upanişad, 1951). "This Self (i.e., the subtle body) is surely in the heart. There are a hundred and one of the (chief) nerves. Each of them has a hundred (division). Each branch is divided into 72 thousand sub-branches. Among them moves the Vyāna" (Praśna Upanişad) (Eight Upanişads, 1957).

There are many clues in the Upanişads that the Self is located in the embryo brain region in the center of the brain. For instance, very often the Self is simply described as being located in the middle. "After meditating on the Self seated in the middle of the heart like a lamp placed inside a vessel of the size of a thumb and of the form of smokeless flame (the Self manifests himself)" (Paingala Upanişad) (Principal Upanişads, 1989). "All deities worship that adorable one, the seated in the middle, who pushes the prāna upward and impels the apāna inward" (Kaţha Upanişad) (Eight Upanişads, 1986). “... in the middle (between the two parts) there comes into being the divine person, the person, with a thousand eyes, a thousand feet and a thousand arms..." (Subāla Upanişad) (Principal Upanişads, 1989) ("between the two parts"- the two hemispheres of the brain). These would all appear to be clear references to the embryo brain region. "Therein the individual soul who has established himself in the middle of the eyebrows..." (Paingala Upanişad) (Principal Upanişads, 1989). It so happens that the spot in the middle of the eyebrows, the mystical third eye of Shiva, is directly in line with the embryo brain region in the middle of the brain. 
We learn from neurophysiologists that when pieces of midbrain are isolated from the brain, the cells continue to fire spontaneously and in a sustained manner (Remond 1972). By "firing" is meant "synapses"- the nerve cells acquire electrical properties. When one considers that by the fifth week after fertilization the embryo cranium is bulging with midbrain, and given the spontaneous nature of midbrainal activity independently of the higher regions, it is apparent that we have a mental life from a very early age. This spontaneous firing of the midbrain is what the Bŗhadāranyaka Upanişad is referring to when it says, "it thinks as it were and quivers, as it were" "as in dream the mind vibrates" (Mānndūkya Kārikā) (Eight Upanişads, 1957). Krishnananda says, "Even if there is a blazing sun in dream it is the mind shining" (Bŗhadāranyaka Upanişad, 1984). The midbrain "shines" in the sense of spontaneous firing of nerve cells. "As from a blazing fire sparks of like form issue forth by the thousands even so many kinds of beings issue forth from the Immutable..." (Māñdūkya Upanişad) (Principal Upanişads, 1989).

The fact that the midbrain is directly connected with the eyes is the clue that it is the source of dreams. The Maitreyi Upanişad tells us that "The person who is in the eye, who abides in the right eye, he is Indra and his wife abides in the left eye... There is a channel extending from the heart up to the eye and fairly fixed there. That is the channel which serves both of them, by being divided in two though but one" (Chāndogya Upanişad, 1983). "That is the eye in a man through which one sees in a dream" (Vedic text) (Eight Upanişads, 1957). The visual pathway runs forward from the midbrain to the eyes, and backwards from the midbrain to the visual cortex at the back of the brain. The visual pathway is indeed "divided in two though but one" as the Maitreyi Upanişad says, in order to serve both eyes.

Dreams involve visual image and are therefore inextricably tied in with the visual pathway. Śańkarācārya says, "and then a man whose eyes are plucked out should not perceive blue yellow etc., in dream" (Commentary on Aitareya Upanişad) (Eight Upanişads, 1957). This is an allusion to the fact that only the color cone receptors in the retinae of the eyes can produce a color image in our dreams. It is apparent then that a dream image originates in the midbrain as an electrical impulse which then travels forward to the eyes where the impulse is converted into a color image — this is why dreams always involve eye movement either rapid or non-rapid - and from the eye back along the visual pathway to the visual cortex where the image is actually registered. It is therefore understandable that brain patterns during REM sleep (desynchronized) are practically identical with those during arousal (Gregory 1987). The visual pathway comes into operation in both cases. Krishnananda says, "As in dream, so in waking, as in waking so in dream" (Bŗhadāraņyaka Upanişad, 1984). The midbrain "thinks as it were, and quivers, as it were. For being one with dreams, it goes beyond this (waking) world" (Bŗhadāranyaka Upanişad, 1951).

"This is but the middle-part of the Self" (Chāndogya Upanişad, 1983); "Madhye āsinam-sitting in the middle - sitting in the space inside the lotus of the heart, shining in the intellect as revealed knowledge" (Śańkarācārya's Commentary on the Kațha Upanişad) (Eight Upanişads, 1986). "Abiding in the middle place, man sees both places, this and the place of the other world" (Bŗhadāranyaka Upanişad, 1978). It is submitted that in the midbrain is located the cosmic intelligence, Brahman and Atman or the individual Self operates through the hypothalamus and thalamus as well as the brainstem. "The Supreme dwells in close fellowship with the individual Self in the cave of the human intelligence" (Rangaramanuja - quoted by Radhakrishnan) (Chāndogya Upanişad, 1983). There are dozens of similar references in the Upanişads to this "guhā," this secret place, this cavity, this cave in the intellect which is $\bar{a} k \bar{a} s$ : : space. "It is used as a name of the Supreme, because like a space, Brahman has no body and is subtle" (Radhakrishnan) (Principal Upanişads, 1989). There 
is literally a cavity or space associated with the midbrain. The fourth ventricle. A broad shallow rhomboid-shaped cavity that extends from the upper cervical spinal cord to the cerebral aqueduct of the midbrain (Carpenter 1978). "The fourth state, Turiya" "the ether of the heart?" And it does arguably resemble the broad leaf of a lotus plant; hence the many references to the "lotus of the heart."

There are many references in the Upanişads to the Self being "unborn." "This great, unborn soul is the same which abides as the intelligent (soul) in all living creatures, the same which abides as ether in the heart; in him it sleeps; it is the subduer of all, the Ruler of all, the sovereign lord of all beings" (Brhadāranyaka Upanişad, 1978). It is only when one grasps the significance of the sleeping state that the reference to the Self being unborn can be understood. From conception onwards the embryo is asleep, and the adult sleeper reverts precisely to that embryonic state of mind. The Self is located in the embryo brain region and preserves its embryonic identity. It is in this sense that the Self is "unborn." When an adult goes to sleep he/she mentally reverts to the mother's womb. "The talkers vouch indeed for the birth of that very unborn, positive entity. But how can a positive entity that is unborn and immortal undergo mortality?" (Mānndūkya Kārikā) (Eight Upanişads, 1957) "(The Self) without being born (appears to be born in various ways), it follows that He is born on account of Māyāa alone" (Mānndūkya Kārikā) (Eight Upanişads, 1957). As Ŕg Veda says, "It is the controller of the body, the unborn part, which survives death."

\section{De Anima}

Aristotle's work is called De Anima which is Latin for "On the soul." The first thing to be noted is that this is obviously not the actual title that Aristotle gave his work. In fact, Aristotle's original work no longer exists and we only know of his writings as something that has passed through the hands of many editors and many different translators over the millennia. In fact, the English word "soul" conveys nothing of the meaning of the Ancient Greek word psyche. "The psyche, for Aristotle, is that in virtue of which something is alive. The most accurate translation of the term into English would be 'principle of life' or "principle of animation" (Lawson-Tancred 1986). Aristotle's broad term psyche has been diversified in the hands of modern philosophers from Descartes onwards to mean "soul," "mind," or "consciousness" and indeed modern philosophers tend to follow Descartes and take a subjective or first-personal approach to all these various issues. Indeed Aristotle is considered to be old-fashioned or too simplistic with his objective or third-personal discussion of the psyche, but we will find that it is precisely the way that Aristotle discusses the functions of the psyche as something that enjoys an eternal existence independently of the body and yet at the same time is inextricable tied up with the arrangement and functioning of the body that makes his theory virtually identical with the Upanişads. For Aristotle, the psyche is the form of a living being and this is precisely what the inner self is as well.

I have already outlined all the various functions of the embryo brain region of the brain and so I have demonstrated that the inner self has form and functions. In a like manner, the concepts of form and functions are very closely connected for Aristotle. It is because of a living thing's form that it can perform its functions, and conversely if you know its functions you can know its form. It is virtually a truism to state that the embryo brain of a cat will have the form of an embryo brain of a cat and it will produce in the cat after it is born all the various functions that a cat can perform and by virtue of this living being performing those functions we can know that we are dealing here with the form of a cat. Truism or not this is Aristotle's theory in a nutshell and I for one agree with him. In terms of Hinduism, a cat has the inner self of a cat and will therefore perform the 
functions of a cat. What's more this form of being a cat is indelibly stamped on this being, and it will continue to be able to perform its functions of being a cat even if any or all of those functions are only being intermittently utilized; this thing that has the form of a cat cannot change its nature. Aristotle's psyche is the First Actuality of the living being and that is precisely what the inner self is as well. The second Actuality is the body in the actual performance of its functions. This is Aristotle's entelecheia, upon which all life depends. It is often objected that merely asserting as Aristotle does that the forms of living beings be called "souls" is not sufficient to explain what is peculiar to those things. That is of course true but we now know that these "souls" are actually the embryo brains of those living beings, and as such they do literally explain not only what is peculiar to those beings, but indeed they explain everything about them including their essence, their form, their capacities, and their functions.

As a general rule, the two main preoccupations of Presocratic Greek philosophy that Aristotle had to deal with were to find "an explanation of the capacity for self-movement displayed by living things and their no less remarkable capacity for various kinds of cognition" (Lawson-Tancred 1986). Over the millennia, the debate started by the Ancient Greeks has raged whether the "soul" is substantial or insubstantial and if substantial what sort of substance is it, whether it is "physical" or "spiritual," and whether a "spiritual" soul can exist in a "physical" body or do the body and soul both have to be spiritual in order to co-exist, or indeed whether body and soul both have to be physical. In Presocratic philosophy, the standard view was that both body and soul can be physical. Generally speaking, the physical stuff the soul was composed of was one of the elements fire, air, and water or indeed a combination of these. Aristotle when dismissing these theories as being way too naïve drew some consolation in the fact that there was at least no theory that the soul was composed of the fourth element, earth. There was indeed another theory that the soul was composed of atoms that Aristotle largely dismissed as being essentially a soul composed of fire theory. This is a very simplistic overview of the Presocratic theories, and in fact there were some individual theorists like Anaxagoras with his nous, or mind as soul and Empedocles with his logos, or proportion as soul, which Aristotle tried to dismiss quite unconvincingly. There is also the Pythagorean theory that the soul consists of numbers which Aristotle rejected. Indeed this theory is generally taken to be ridiculous and stems from an over-exalted regard that Pythagoras had for mathematics. One wonders however whether Pythagoras won't eventually have the last laugh, because the soul might turn out to be nothing but information recorded in binary data, which is nothing but numbers. To the Pythagoreans is also attributed a very unmaterialistic notion of soul as "a substance of quite a different kind from those that compose the world, to whit an immortal god trapped in a succession of animate and even inanimate bodies" (Lawson-Tancred 1986).

Broadly speaking, Aristotle is regarded as being the father of biology because he is considered to have put forward a Functional Approach in his ruminations about the "soul" that largely fits in with the mindset of modern scientists. But we will see that all the functions that he discusses as being evidence of the workings of the soul or the form and matter of the soul are the same or very similar to the functions that the Upanişads ascribe to the inner self. Broadly speaking, the embryo brain of a cat will have the specific form and matter of the embryo brain of a cat and a living creature will be born that has the "set of attributes" of a cat. What's more, throughout the life of this cat, the embryo brain region consisting of the brainstem, hypothalamus, thalamus, and midbrain will be the natural and appropriate controller of the body of that cat. There is nothing here that a modern biologist would disagree with and so Aristotle can be taken to be the father of the biology, but the fact 
remains that Aristotle's whole discussion is based on the form and matter or substance of the "soul" so there is nothing here that a Hindu versed in the Upanişads will disagree with either.

Just like in the Upanişads, the self is often described as being located in the "heart" so too with Aristotle the location of his soul was likewise taken to be the "heart" (this is the Instrumentalist or Heart theory of Nuyens) (Lawson-Tancred 1986). The interesting fact is that for both Hinduism and for De Anima the actual functions or attributes that the inner self or the "soul" are said to perform or demonstrate actually all come from the embryo brain region, the brainstem, hypothalamus, thalamus, and midbrain. The fact is that the embryo brain region is the "heart" of the brain. Aristotle said that the soul was "the first entelechy of a natural body endowed with organs" (Lawson-Tancred 1986). Substitute his word psyche with the Sanskrit word Atman or inner self and you have got classic Hinduism. Recall the quote from $\mathrm{Rg} V e d a$ earlier "It is the controller of the body, the unborn part, that survives death."

Aristotle's word eidos which is translated as form can mean on the one hand "the principle of organization of a thing which leads it to have its particular existence: on the other, in the sense that is usually translated 'species,' it means a sub-group of a genus or kind" (Lawson-Tancred 1986). Also Aristotle's word ousia is generally translated as "substance" but it can also mean "being" or "essence" and in Aristotle's metaphysics in general it takes on a much wider meaning than simple "substance." Aristotle asserts that forms are substances and that souls are forms therefore concluding that souls are substances (Lawson-Tancred 1998).

Once it is realized that the "soul" is the embryo brain region, then there is no ambiguity here whatsoever. For the embryo brain of a particular living being is at once the principle of organization of that being as well as defining the species that being belongs to and the substance or essence of that being, in addition to which the embryo brain does consist of matter in the conventional sense of the word. It is composed of material; it can be examined and studied; it has certain parts and dimensions and texture. The embryo brain as soul is indeed immersed in the matter of the body. In book Zeta of his Metaphysics, Aristotle also favors a description of the soul as the substrate (to hupokeimenon). This again is most a propos for the embryo brain of any living being for it really is the logos of any living thing, and it represents the "fulfilment or realization" of the particular thing just as Aristotle requires. You can see that the embryo brain ticks all the boxes when it comes to Aristotle's discussion of the form, matter, and substance of soul and indeed Aristotle himself strongly hints that the soul is located in the embryo (see the quotation from Generation of Animals at the conclusion of this article).

We can also better understand Aristotle's insistence that the soul consists of form and matter and their composite.

It is standard Aristotelian doctrine that there are gradations in the realization of any potential. He expresses this by saying that a composite particular may have a first and second actualization. It is in virtue of the first of these that its matter is so arranged as to render it capable of performing its characteristic functions and it is in virtue of the second that it "actually" performs them. (Lawson-Tancred 1986)

During the embryo period, we see the first actualization of the embryo brain, and then after the creature is born we see the second actualization of the embryo brain as the embryo brain region of the developed brain. In other words, the embryo brain region continues to operate as the soul of the being throughout its life and the being will continue to have all its specific attributes and perform all its functions as a being of a particular species or genus precisely because of the continued operation of the embryo brain region in its secondary actualization. 
The embryo brain region and the body of that being do indeed become a composite and both the matter of the soul and the matter of the body are perfectly homogenous. This is why Aristotle refers to the substance of the soul in book Gamma of his Metaphysics as the what-it-was-to-be-that-thing of a thing (Lawson-Tancred 1998). "It suggests the idea of what something was all along going to, destined to, become" (Lawson-Tancred 1998). The first actualization of the soul is the embryo brain when the being is an embryo. But because the second actualization of the soul is the embryo brain region in the developed brain, then the ousia or essence of the soul can now only be referred to in the past tense. Your what-it-was-to-be-that-thing was your own embryo brain when you were an embryo! Your embryo brain was your first entelechy; the embryo brain region in your brain is your second entelechy. It's just that simple.

Aristotle then passes on to a detailed discussion of the various functions of the soul that are responsible for various attributes and capabilities of living beings. Call it the first comprehensive attempt to specify all the essential functions that can be found in living beings - typically in human beings - although the functions are arranged in a hierarchical fashion from the most basic like the nutritive function and reproductive function that will be typical of all beings including plants through to functions like imagination that will be found only in humans. This is why Aristotle is regarded as the father of biology. Indeed it is said of him that he anticipated the DNA as the First Principle. See the remark of Max Delbrueck, a professor at the California Institute of Technology, that "if the Nobel committee were able to award the prize for biology posthumously, they should consider giving it to Aristotle for the discovery of the principle of DNA" (Lawson-Tancred 1986).

Because modern biologists completely ignore the God factor in De Anima we can fairly readily come up with an Aristotelian First Principle they would be happy with:

Biology is the source of Consciousness;

DNA is the source of Biology;

Ergo DNA is the source of Consciousness.

Aristotle devotes the bulk of his discussion to sensory perception which is classic Hinduism and can have no meaning other than the soul being located in the embryo brain region. Another function of the soul is phantasia which is generally translated as "imagination." We have seen that the visual pathway runs forwards from the midbrain to the eyes and backwards from the midbrain to the visual cortex. The midbrain as the source of dream imagery would also be the source of phantasia, especially as Aristotle treats it as an "interpretative mental act in connection with perception" (Lawson-Tancred 1986) as well as "a specific faculty that we possess to produce in our minds imagery related to, but not identical with, that of the sense" (Lawson-Tancred 1986). The soul is also responsible for the motivation faculty in living beings. We have seen that the hypothalamus organizes total acts of aggression, timidity, mating, and sexual behavior in animals, and as for the causes of movement in animals, then we need look no further than the motor thalamus that has extensive afferent connections to the premotor and primary motor cortex (Fang et al., 2006; Orrison 2008). Refer to earlier quote from Maitreyi Upanishad about the "Self moving about yet unmoving." The motor thalamus is Aristotle's "unmoved mover," and is an adjunct of God as the Unmoved First Mover.

Aristotle also discusses the intellect as an "affection" of the soul. Here again "Aristotle's account is manifestly open to the charge of attempting too great an assimilation of thinking to perception and especially to seeing" (Lawson-Tancred 1986), so the operations of the hypothalamus and midbrain can largely account for this as well. As regards his notion of "the active intellect and passive intellect" even Aristotle's immediate 
successor at the Lyceum (Theophrastus) was already interpreting this as a distinction between "the mind in potentiality and the mind in actuality" (Lawson-Tancred 1998). "Aristotle argues, in Metaphysics IX, that actuality is prior to potentiality. This means, among other things, that a potentiality must be understood in terms of some corresponding actuality (Met. IX 8 1049b12-17)" (Shields 2012). In book Lambda of his Metaphysics, "the Supreme Being is perpetually engaged in an activity that Aristotle calls noesis noeseos, which on the surface appears to mean 'thinking of, i.e., about, thinking"” (Lawson-Tancred 1998). This has clear counterparts in the cosmic intelligence Brahman and the individual self Atman of the Hindus. Evidently, the only way we can know anything about the "potentiality" which is Brahman is by inquiring into the "actuality" which is $\bar{A}$ tman or the inner self.

It is clear from the following passage from De Anima (Shields 2012) that the mind in potentiality is the separable and immortal part of the soul for Aristotle. It is only in as much as the individual soul is able to participate or share in the cosmic intelligence that living beings are able to think at all. It is in this sense that the cosmic intelligence is the productive mind and the individual soul is just a passive mind that is indeed perishable. Here again there are clear counterparts in Hindu theory.

Since just as in all nature something is matter for each genus (this is what is all those things potentially) and something else is the cause and is productive by producing all things (just as an art stands to matter), these differences must also exist in the soul. And one sort of mind exists by becoming all things, while another exists by making all things, as a sort of disposition like light. For in a way light makes potential colors into actual colors. And this mind is separable (chôristos), unaffected, and unmixed, since it is essentially in actuality. For the producer is always more honorable than the patient, and the principle is more honorable than the matter. Actual knowledge is the same as the object; but potential knowledge is prior in time in the individual, but on the whole, it is not prior even in time. But it is not the case that it sometimes thinks and sometimes does not think. Having been separated (choristheis) this is alone what it is, and this alone is immortal and eternal—but we do not remember because, while this is unaffected, the passive mind is perishable — and without this, nothing thinks. (III 5 430a10-25)

\section{Conclusion}

It is only when we come to the realization that the divine part of the brain is the part of the brain that operates during our sleep, both dreaming and deep sleep, that we are able to come to a correct interpretation of the Upanişads. By the same token Aristotle in his Nicomachean Ethics refers to Endymion as the God in all of us that is permanently asleep (X 8 1074b15-18) (Shields 2012), we have seen that from conception onwards that the embryo is in a state of sleep and that the embryo brain region is the part of the brain that operates during our sleep. There cannot be any doubt that the divine and separable part of our brain is in that embryo brain region whether you want to call it the divine inner self along with the Hindus or whether you want to call it the psyche or the nous along with Aristotle. "In a person, indeed this one first becomes an embryo" (Aitareya Upanişad). In the following quote from Aristotle's Generation of Animals, the word "origin" is synonymous with First Principle. There is no doubt whatsoever where the "soul" is located.

So, if there is such a part, which must be present in animals, one which has the origin and end of the entire nature, this must come to be first - as motive capacity, first, while as a part of the end it must come to be along with the whole... And on account of this, the part having the origin comes to be first, and then, following it, the upper trunk. It is for this reason that the parts around the head and the eyes appear largest in embryos at the start, while those below the umbilicus, such as the legs, are small. For the lower parts are for the sake of the upper and are neither part of the end nor generative of it. (742b12-17) 
By five weeks after conception, the embryo cranium is bulging with midbrain that is firing spontaneously. This is what-it-was-to-be our soul.

\section{Works Cited}

Austin, C. R. \& Short, R. V. (Eds.). "The Fetus and Birth.” G. C. Liggins. Embryonic and Fetal Development 2 (1972).

Bartholomew, B. Y. "Inner Self Located." Indian Philosophical Quarterly. $18.4 \quad$ (1991). $<$ http://unipune.ac.in/snc/cssh/ipq/english/vol18_4.htm>.

Carpenter, M. B. Core Text of Neuroanatomy. Baltimore: Williams \& Wilkins, 1978.

Chāndogya Upanişad. Calcutta: Advaita Ashrama, 1983.

Doer, E. Bŗhadāraņyaka Upanişad. Delhi: Nag Publishers, 1978.

Eight Upanişads Vol. 1. Calcutta: Advaita Ashrama, 1986.

Eight Upanişads Vol. 2. Calcutta: Advaita Ashrama, 1957.

Fang, P. C., Stepniewska, I. \& Kaas, J. H. "The Thalamic Connections of Motor, Premotor, and Prefrontal Areas of Cortex in Prosimian Primate (Otolemurgarnetti).” Neuroscience 143.4 (2006).

Gregory, R. L. (Ed.). The Oxford Companion to the Mind. See generally, Brain Development, Catecholamines, Dopamine Neurones in the Brain, Nervous System, Neuroanatomical Techniques, Neuropeptides, Neurotransmitters and Neuromodulators, Visual System: Organization, 1987.

Lawson-Tancred, H. Aristotle, De Anima (On the Soul) (Classics). Penguin Books Ltd. Kindle Edition. 1986.

Lawson-Tancred, H. Aristotle. The Metaphysics (Penguin Classics). Penguin Books Ltd. Kindle Edition. 1998.

Orrison Jr., W. Atlas of Brain Function. New York: Thieme Medical Publishers Inc., 2008.

Pecile, A. \& Muller, E. E. (Eds.). The Ontogenesis of Hypothalamic-Hypophysiotropic Releasing Factor Regulation of High Secretion. Selna L. Kaplan \& Melvin M. Grumbach. International Symposium on Growth Hormone; Proc. of 2nd Int. Symp. on Growth Hormone; Milan. 1971.

Remond, A. (Ed.). Handbook of Electroencephalography and Clinical Neurophysiology, Volume 2A, Section 5, Thalamo-Telencephalic Circuits: A Neuroanatomical Survey, 2A-86, Volume 2C, Section 4, Thalamic Origin of Cortical Rhythmic Activity, 2C-90, Section 5, Reticular Influences on Thalamo-Cortical Activity, 2C-119. 1972.

Shields, C. The Oxford Handbook of Aristotle (Oxford Handbooks). Oxford University Press. Kindle Edition. 2012.

The Bŗhadāranyyaka Upanişad. Sri Ramakrishna Math; Madras. 1951.

The Bŗhadāranyyaka Upanişad. Swami Krishnananda; The Divine Life Society, Tehri- Garwahl. 1984.

The Bŗhadāranyaka Upanişad. Swami Sivananda; The Divine Life Trust Society, Tehri-Garwahl. 1985.

The Principal Upanişads. S. Radhakrishnan; Oxford University Press, Delhi. 1989. 